
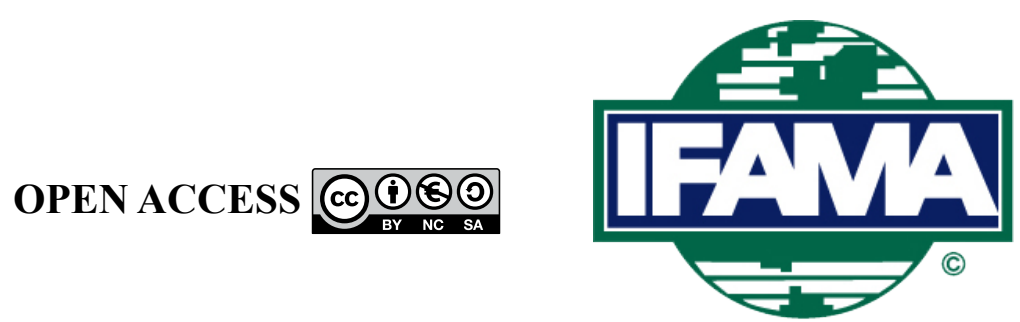

International Food and Agribusiness Management Review

Volume 25, Issue 2, 2022; DOI: 10.22434/IFAMR2021.0055

Received: 3 May 2021 / Accepted: 26 October 2021

\title{
Effects of international trade on world agricultural production and productivity: evidence from a panel of 126 countries 1962-2014
}

\section{RESEARCH ARTICLE}

\author{
Lingran Yuan ${ }^{\mathrm{a}}$, Qizheng Zhang ${ }^{\mathrm{a}}$, Shuo Wang ${ }^{\mathrm{a}}$, Weibin $\mathrm{Hu}^{\mathrm{b}}$ and Binlei Gong ${ }^{\oplus \mathrm{c}}$ \\ ${ }^{a}$ PhD Student, ${ }^{b}$ Research Fellow, School of Public Affairs, Zhejiang University, \\ 866 Yuhangtang Road, Hangzhou, 310058, China P.R. \\ ${ }^{c}$ Associate Professor, Academy of Social Governance and China Academy for Rural \\ Development, Zhejiang University, 866 Yuhangtang Road, Hangzhou, 310058, China P.R.
}

\begin{abstract}
General Agreement on Tariffs and Trade (GATT) was notable in largely excluding agriculture whereas the World Trade Organization (WTO) brought agriculture into the world trade rules. This article aims to evaluate the impacts of trade on agriculture production and productivity, especially the changes between the GATT and WTO periods. Using a panel of 126 countries from 1962-2014, this article derives not only spillover effects that were overlooked, but also provides more accurate productivity than was estimated with bias in literature for both periods. We find that trade hindered agriculture production and productivity in the GATT period but improved agriculture production and productivity in the WTO period.
\end{abstract}

Keywords: agricultural spillovers and productivity, spatial econometrics and model averaging, developed and less developed countries, GATT and WTO periods

JEL code: D24, F63, Q17, O40, R1

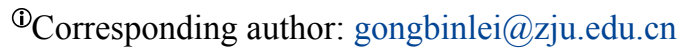




\section{Introduction}

The General Agreement on Tariffs and Trade (GATT) was a multilateral agreement that had regulated international trade since 1948, aiming to substantially reduce tariffs and other trade barriers after World War II. Although some breakthroughs were achieved, the development of international trade was not satisfactory in the context of the Cold War. This situation changed dramatically in the 1990s after the dissolution of the Soviet Union. The lack of rivalry and tension between the major powers in the Eastern Bloc and the Western Bloc provided a great opportunity for international trade and global cooperation. The World Trade Organization (WTO) was formed as a replacement for the GATT in 1995 with the purpose of supervising and liberalizing international trade; it has a more permanent structure and is more powerful in dealing with international economic affairs.

Many economists (e.g. Disdier and Head (2008), and Michaels and Zhi (2010)) study the interactions and international trade across countries using a gravity model, where bilateral trade follows depends on economic sizes and distance between the two countries. Some other scholars (e.g. Aghion and Griffith (2008), Gong (2018b) and Hansson and Henrekson (1994)), however, are more interested in the effect of international trade on economic growth, where productivity and efficiency analysis is usually adopted. Based on the latter approach, this article aims to evaluate the impacts of international trade on world agricultural production. GATT was notable in largely excluding agriculture from trading rules. The major breakthrough in the Uruguay Round, which established the WTO, was to bring agriculture into the world trade rules, freezing and then substantially reducing agricultural protection (or at least trade distortion) in the developed world. Therefore, it is interesting to explore the changes between the GATT and WTO periods, between GATT/WTO members and non-members, and between developed countries (DCs) and less developed countries (LDCs).

The new growth theory (e.g. and Lucas (1988) and Romer (1986)) proposes that the international economic interflow is a major driver of economic growth. Hansson and Henrekson (1994) recommend using productivity growth instead of GDP growth as the proxy of economic growth to evaluate the impact of international trade, since international trade is a part of measured GDP. Moreover, new trade theory believes international trade is a key factor for promoting technological progress and therefore functions as a productivity stimulus. Grossman and Helpman (1993) illustrate that international trade improves productivity through two channels: imports can bring not only commodities that cannot be produced domestically, but also the information needed to produce them, whereas exports can bring suggestions and requirements from foreign buyers that push exporters to update their technology and accumulate management skills from other countries. Aghion and Griffith (2008) point out that international trade can intensify the level of competition and innovation, which consequentially increases productivity.

Existing studies (e.g. Alcalá and Ciccone (2004), Chanda and Dalgaard (2008), Frankel and Romer (1999) and Miller and Upadhyay (2000)) often adopt a production function to estimate productivity and then evaluate the effect of international trade on the estimated productivity. Many of them focus on the impact of trade on macroeconomic growth and total factor productivity using cross-country data. Alcalá and Ciccone (2004) who empirically investigated the impact of trade on a country's total factor productivity using the country's geographic characteristics as instrumental variables. After controlling for country size, geography and institutional quality, the elasticity of productivity with respect to real openness is about 1.2 , which implies that an increase in a country's trade openness from the thirtieth percentile to the median level leads to an $80 \%$ increase in productivity. However, fewer studies have empirically examined the impact of trade on total factor productivity in agriculture using cross-country data, and most of such studies take one region or one country as an example. Hassine and Kandil (2009) found a positive contribution of trade openness to improvements in agricultural productivity in the Mediterranean region. Gong (2018b) empirically examines the impact of trade on total factor productivity in Chinese agriculture using provincial panel data in China, and the results show that a $1 \%$ increase in agricultural exports can raise agricultural productivity by $0.037 \%$, but agricultural imports do not significantly affect agricultural productivity. Yoo et al. (2012) empirically examined the effect of trade openness on total factor productivity in Korean agriculture using Korea as an example, and the results 
showed that both the increase in agricultural imports and exports favorably boosted total factor productivity in Korean agriculture, with the growth effect brought by imports being more pronounced. The production function is usually assumed to be a conventional non-spatial model in the form $y_{i t}=X_{i t} \beta+\alpha_{i t}+\varepsilon_{i t}$ where $y$ and $X$ are output and inputs, while $\alpha_{i t}$ is the productivity. In recent years, however, many economists (e.g. Areal et al. (2012) and Caragliu and Nijkamp (2012)) consider cross-sectional dependence in the production function, as interactions and spillovers exist in the production process across units. ${ }^{1}$ As a result, some scholars (e.g. Cohen and Paul (2004) and Gong (2017)) use the spatial production function (or spatial cost function) $y_{i t}=X_{i t} \beta+\rho \sum_{j=1}^{N} \omega_{i j} y_{j t}+\alpha_{i t}+\varepsilon_{i t}$ in various industries where the output of a unit not only depends on its own input and productivity, but also on the output of other units. The elements $\omega_{i j}$ in the spatial weights matrix account for the dependence between units $i$ and $j$, which is often measured through bilateral trade in crosscountry analysis. Using the conventional non-spatial model, existing studies may have two disadvantages if cross-country interactions exist in world agricultural production. First, spillover effects due to international trade may be overlooked when studying the effect of trade. Second, the ignorance of such spillovers further causes $\rho \sum_{j=1}^{N} \omega_{i j} y_{j t}$ to be mistakenly included in productivity, which leads to biased estimation in terms of the effect of international trade on productivity, because $\omega_{i j}$ includes information on international trade.

Considering these two puzzles, this article builds a spatial production function to model country-level agricultural production, where bilateral trade for each pair of nations is utilized to estimate the spillover effects due to international trade. In order to more comprehensively describe the overall interactions across countries, this article jointly considers geographic dependence and trade dependence using a model averaging method. Consequently, more accurate total factor productivity (TFP) can be derived, which allows us to better evaluate the unbiased effect of international trade on productivity. To summarize, this article explores the impacts of international trade on world agriculture through two channels: spillover effects and productivity growth.

There are four central contributions of this article: (1) it extends the effects of international trade on spillover effects, in addition to an unbiased effect on productivity using a spatial model; (2) it employs a model averaging method to jointly consider the geographic-wide and trade-wide dependence across countries; (3) it evaluates not only the effect of trade volume, but also the effects due to the characteristics and distributions of trade; and (4) it compares the aforementioned effects of international trade on agriculture between the GATT and WTO periods, between GATT/WTO members and non-members, and between DCs and LDCs.

Using a panel of 126 countries from 1962-2014, the empirical results show that: (1) During the GATT period, geographic spillover effects (indirect effects are 0.059) were positive, whereas international trade caused negative spillover effects (indirect effects are -0.056), which implies that the advantages of international trade were enjoyed in the second period. (2) The existence of spillover effects due to international trade also implies the necessity to use spatial models, which not only capture cross-country interactions, but also avoid the biased estimation of TFP. (3) The averaging weights assigned to international trade international trade during the full period is 0.84 , which increased from 0.65 to 1 in the WTO period, indicating that trade is relatively more important than geographic proximity in global interactions. (4) More international trade had a very similar negative effect on productivity for DCs and LDCs in the GATT period, but a larger positive effect on productivity for DCs than LDCs in the WTO period; On average, a $1 \%$ increase in the total volume of international trade could decrease agricultural TFP by $0.034 \%$ during the GATT period, but can increase agricultural TFP by $0.043 \%$ during the WTO period. (5) The GATT did not provide a bonus for its members, while the WTO offered significant benefits from international trade for its members, especially for LDCS. In the WTO period, LDCs without WTO membership can achieve a $0.042 \%$ increase in agricultural TFP from a $1 \%$ increase in the total volume of international trade, which can further improve by $0.004 \%$ with WTO membership. (6) Exports outperform imports in productivity enhancement and the diversification of trade

\footnotetext{
${ }^{1}$ In the agricultural sector, the spread of agricultural technologies through international trade is one of the drivers that may lead to positive spillovers. Moreover, free trade makes it possible for countries to generate more agricultural products with their competitive advantages. Given the same amount of total inputs, the total production can increase if a larger share of the output is from those productive agricultural products. On the other hand, however, trade dumping and destructive competition can be counterproductive (Brown-Kruse, 1991). Furthermore, externality problems occur in agriculture across countries, such as excessive carbon emissions that causes climate change, as well as overuse and pollution of water resources, can also generate negative spillover effects.
} 
partners is not beneficial in productivity growth. On average, a one percentage point increase in the export ratio can raise total factor productivity by more than $0.1 \%$ over the full period. To summarize, international trade hindered agricultural growth due to negative spillover effects and the negative effect on productivity in the GATT period, but boosted agricultural growth due to the positive spillover effects and the positive effect on productivity in the WTO period. The empirical results provide evidence that WTO bring agriculture into the world trade rules, which was largely excluded in GATT.

The remainder of the article is structured as follows: Section 2 introduces the model and methodology, Section 3 provides data descriptions, Section 4 reports and analyzes the estimation results, and Section 5 concludes.

\section{Model}

This section first uses a spatial production model that can separately measure the spillover effects due to international trade, as well as geographic proximity, across countries. Then, a model averaging method is adopted so that these two dimensions can be considered jointly, which derives more accurate total factor productivity (TFP). Finally, this article analyzes the impacts of international trade on TFP.

\subsection{Spatial production function and trade-driven spillover effects}

A non-spatial production function with Cobb-Douglas formation is adopted in many studies (e.g. Petrick (2016), Gong (2020b), and Gong and Sickles (2020)) to derive productivity. A normal production function with Cobb-Douglas formation has the form. ${ }^{2}$

$$
Y_{i t}=\alpha_{0}+X_{i t} \beta+\tau P_{t}+\gamma I_{i}+\varepsilon_{i t}
$$

where $y_{i t}$ accounts for the agricultural output in country $i$ at time $t, X_{i t}$ is a $(1 \times \mathrm{K})$ input vector that measures the input portfolio of country $i$ at time $t . \beta$ is a $(\mathrm{K} \times 1)$ parameter vector of the input elasticities and $\varepsilon_{i t}$ is an i.i.d. disturbance with zero mean and variance $\sigma_{\varepsilon}{ }^{2}$. $P$ is a group of year dummy variables and $I$ is a group of country dummy variables, which will capture the fixed effects over time and across countries, respectively. $\alpha_{0}+\tau P+\gamma I$ measures TFP in logarithm.

However, the non-spatial agricultural production function relies on the assumption that agricultural production in each country is independent, which ignores cross-country interactions. In the context of globalization, this assumption is invalid and may lead to a biased input-output relation. This article employs spatial techniques into the agricultural production function to address the potential spillover effects across nations. The Spatial Autoregressive Model (SAR) is one of the most popular spatial models utilized in econometrics (Anselin, 2001, 2013; Cliff and Ord, 1973; Hardie et al., 2001; LeSage and Pace, 2009; Ord, 1975). SAR captures endogenous interaction effects by estimating the cross-sectional dependence on explained variable $y$. Consequently, in our study, the output of a nation depends not only on its own inputs and productivity, but it is also jointly decided by the output of other nations, known as spillover effects. This article employs the SAR model to the world agricultural production function at country level in the form:

$$
y_{i t}=\rho \sum_{j=1}^{N} \omega_{i j} y_{j t}+\alpha_{0}+X_{i t} \beta+\tau P_{t}+\gamma I_{i}+\varepsilon_{i t}
$$

where $\omega_{i j}$ is the element in the $i$-th row and $j$-th column of the $(N \times N)$ spatial weights matrix $W$, which accounts for the cross-sectional dependence between nations $i$ and $j$. Then $\rho$ is a parameter to be predicted that measures the existence, sign and magnitude of the spillover effects. Endogeneity issues may occur in the production function, as some information available to the producers to adjust their input portfolios is unobservable to scholars (Ackerberg et al., 2015). The control function method recommended in Amsler et

\footnotetext{
${ }^{2}$ Some studies (e.g. Chen and Gong, 2021; Zhang et al., 2020) adopts translog production function as the benchmark model or as an alternative model in robustness check. This article uses Cobb-Douglas production function as the main model and then uses translog production function in robustness check.
} 
al. (2016) is employed to test the endogeneity of the inputs, where lagged values of the inputs are utilized as instruments (Levinsohn and Petrin, 2003). For those inputs that are confirmed to be endogenous, this article uses the instrumental variables (IV) method to correct the estimation bias.

The spatial weights matrix $W$ is the tool to define closeness across nations, measuring the magnitude of dependence and interactions according to the first law of geography. This article employs two methods to measure closeness from different perspectives.

1. Geographic closeness. Some studies (Curtis and Hicks, 2000; Roe et al., 2002) adopt geographic proximity to measure the magnitude of cross-sectional dependence and interactions, as neighboring nations and nations that are closer in distance are more affected by each other (Kelejian et al., 2013). In the world agricultural analysis, the geographic weight matrix $W_{1}$ can be built where the elements $\omega_{i j}^{\mathrm{I}}$ are the inverse of the physical distance between nations $i$ and $j$, such that closer nations have greater dependence (Gaigné et al., 2011; Isik, 2004). Mathematically, the elements in $W_{l}$ can be calculated by $\omega_{i j}^{\mathrm{I}}=\left(D_{i j}\right)^{-1}$ where $D_{i j}$ is the Euclidean distance between countries $i$ and $j$.

2. Economic closeness. Some scholars (Druska and Horrace, 2004; Han et al., 2016) use bilateral trade volume to account for the economic connection, which can explain the strong interactions between some nations (e.g. the United States and China), regardless of the great geographic distance. Two countries with a larger volume of agricultural trade are more closely connected and experience more interactions in the agricultural sector. The trade weights matrix $W_{2}$ measures the total volume of the bilateral trade of agricultural products for each pair of countries. Mathematically, the volume of agricultural trade between countries $i$ and $j$ at time $t$ is $\omega_{i j t}^{I I}=$ export $_{i j t}+$ export $_{j i t}$ where export $t_{i j t}$ accounts for the agricultural exports from nation $i$ to nation $j$ at time $t$. The elements $\omega_{i j}^{I I}$ in $W_{2}$ can be calculated by $\omega_{i j}^{\mathrm{II}}=\frac{1}{T} \sum_{t=1}^{T}\left(\omega_{i j t}^{\mathrm{II}}\right)$ so that it reflects the average level of economic closeness during the sample period. Using this matrix can capture the spillover effects due to international trade on world agricultural production.

In summary, two candidates have been employed to measure cross-sectional interactions from different angles: geographic closeness and economic closeness. This article can therefore establish two spatial weights matrices $\left(W_{1}\right.$ and $W_{2}$ ) to reflect multi-dimensional interactions in global agricultural production. In order to meet the requirements of a spatial weights matrix, $W_{1}$ and $W_{2}$ are then adjusted so that they are standardized by row and have zero diagonals. Finally, each of the two spatial weights matrices is introduced into Equation 2 to measure the cross-country interactions in the corresponding dimensions. In other words, geographic-wide and trade-wide dependences can be separately captured.

Solving the spatial production model in Equation 2, this article can then estimate direct effects and indirect effects. The former measure the impacts of the country itself, whereas the latter are the impacts on other nations (Moussa and Laurent, 2015). Accordingly, indirect effects are regarded as a measure of spillover effects in many studies (Han et al., 2016; LeSage and Pace, 2009). Mathematically, the direct effects are derived by averaging the diagonal elements of $(I-\rho W)^{-1} \beta$, while the indirect effects are predicted by averaging the row sums of the off-diagonal elements of $(I-\rho W)^{-1} \beta$. Therefore, the spillover effects due to interactions from different dimensions (geographic-wide and economic-wide) can be calculated, respectively.

It is worth noting that the economic-wide indirect effects can be regarded as spillover effects due to international trade, or trade-driven spillovers, since economic closeness is measured by bilateral trade. The spillovers across countries can be either positive or negative in agriculture (Gong, 2018c): on the one hand, technology spread can achieve positive spillover effects; on the other hand, negative spillovers may exist due to destructive competition. The sign of the overall spillover effects need to be estimated. 


\subsection{Aggregation method: single- to multi-dimensional analysis}

Let us denote $F_{1}$ and $F_{2}$ as the corresponding spatial production functions using $w_{1}$ and $w_{2}$ as the spatial weights matrix, separately. Since $W_{1}$ and $W_{2}$ may both reflect the interactions across countries to some extent, both $F_{1}$ and $F_{2}$ may partially capture the overall spillover effects from different perspectives. As a result, the overall spillover effects from cross-country interactions can be fully estimated only if we find an aggregation method to simultaneously take both dimensions into consideration. In other words, we need to convert the abovementioned two separate single-dimensional spatial analyses into a multi-dimensional analysis.

In order to combine the interactions in both dimensions to utilize all available information and capture the true data generating process (DGP), the relative significance reflected by a series of weights, one for each dimension, must be decided. This article uses the model averaging method, which assigns a weight to every candidate model according to its ability to explain the data when each model may to some extent specify the true DGP (Cho and Kasa, 2017; Malik and Temple, 2009). The weighted average estimation converts separate single-dimensional spatial analyses into a multi-dimensional analysis that fits the data the best and approximates the underlying mechanism. It is worth noting that model selection is a special case of the model averaging method, when all the weight is distributed to one candidate model.

This article uses a jackknife model averaging method proposed by Hansen and Racine (2012), which approaches the minimum expected square errors when the sample size approaches infinity. In recent years, many studies in productivity and efficiency analysis have employed the jackknife model averaging method. Shang (2015) reviews the family of model averaging methods and uses the jackknife method to study the productivity of 112 countries over the period from 1960-2012. Gong (2020a) adopts the jackknife method to predict agricultural productivity in China, while Yuan et al. (2021) uses this approach to estimate world agricultural efficiency.

More specifically, the jackknife method assigns weights according to the 'leave-one-out' cross-validation criterion. The jackknife estimators of the $\hat{y}^{m}=\left(\hat{y}_{1}^{m}, \ldots, \hat{y}_{N}^{m}\right)^{\prime}$ need to be derived, where $\hat{y}_{i}^{m}$ is the fitted value of nation $i$ 's output after its own observations are removed from the regression process of $F_{m}$ using $W_{m}$ as the spatial weights matrix. The weights $W_{m}$ are assumed to be non-negative and sum to one, so the space $\Omega_{2}=\left(w \in R^{2}: w_{m} \geq 0, \sum_{m=1}^{2} w_{m}=1\right)$. The jackknife weights $w^{*}=\left(w_{1}{ }^{*}, w_{2}{ }^{*}\right)$ are achieved by minimizing the cross-validation criteria over weight space:

$$
w^{*}=\underset{w=\left(w_{1}, w_{2}\right) \in \Omega_{2}}{\operatorname{argmin}} C V_{n}(w)=\frac{1}{n} \hat{e}(w)^{\prime} \hat{e}(w)
$$

where $\hat{e}(w)=y-\sum_{m=1}^{2} w_{m} \hat{y}^{m}$

Here $\sum_{m=1}^{2} w_{m} \hat{y}^{m}$ is the weighted average of the jackknife estimator, leaving $\mathrm{e}(w)$ as the weighted average residual. As a result, $w^{*}=\left(w_{1}{ }^{*}, w_{2}{ }^{*}\right)$ measures the jackknife weights assigned to each of the two singledimensional spatial analyses, which reflect the relative importance of geographic and economic closeness on the mutual interference in the agricultural sector. Since $w^{*}=\left(w_{1}{ }^{*}, w_{2}{ }^{*}\right)$ minimizes square residuals, the weighted average spatial production model in Equation 4 is the best fit of the data.

$$
y_{i t}=\sum_{m=1}^{2} w_{m}^{*}\left(\rho_{m} \sum_{j=1}^{N} \omega_{i j}^{m} y_{j t}+X_{i t} \beta_{m}+\varepsilon_{i t}^{m}\right)
$$

The overall spillover effects due to multi-dimensional interactions can also be derived, which is the weighted average of the two single-dimensional spillovers. Mathematically, the overall spillover effects can be calculated by $\sum_{m=1}^{2} w_{m}^{*}\left[\left(I-\rho_{m} W_{m}\right)^{-1} \beta_{m}\right]$. 
A second approach to derive the overall spillover effects can be constructed as follows. First, the weights $w^{*}$ $=\left(w_{1}{ }^{*}, w_{2}{ }^{*}\right)$ are utilized directly to calculate the aggregated spatial weights matrix $W^{*}=\sum_{m=1}^{2} w_{m}^{*} W_{m}$. This new matrix reflects the overall level of interaction across countries, as each element in $W^{*}$ is the weighted average of geographic and economic interactions between two nations. Second, this article uses $W^{*}$ in the spatial model in Equation 2, which derives another estimate of the overall spillover effects $\left(\mathrm{I}-\rho^{*} W^{*}\right)^{-1} \beta^{*}$. This measure of the overall spillover effects also considers interactions in both dimensions and is therefore comparable to the weighted average of the two indirect effects introduced in the previous paragraph. As a result, this article treats this second approach as a robustness check of the overall spillover effects.

In summary, this article employs each of the two spatial matrices $\left(W_{1}\right.$ and $\left.W_{2}\right)$ to model the production process with the concern of geographic-wide and trade-wide interactions, which generate two single-dimensional spillover effects. The jackknife model averaging method is then applied to derive weights, which are utilized to estimate the overall spillover effects. Furthermore, the overall spillover effects can also be predicted directly using the weighted average spatial weights matrix $W^{*}$, which is adopted as a test to confirm the robustness of our estimation on spillover effects.

\subsection{Effects of trade on total factor productivity}

If a conventional non-spatial model is adopted, the spatial part $\rho \sum_{j=1}^{N} \omega_{i j} y_{j t}$ in Equation 2 will be mistakenly included in total factor productivity (TFP), since TFP is a Solow residual. More importantly, the estimated effect of international trade on productivity is biased, as $\omega_{i j}$ in the spatial part includes information on international trade. The spatial production regression and model averaging method not only derive overall spillover effects, but also a more accurate TFP. In the first approach, aggregated TFP is the weighted average of the two TFPs derived by the two candidate models. In the second approach, however, aggregated TFP is estimated directly from the SAR model with $W^{*}$ as the spatial weights matrix.

International trade may have impacts on agricultural production not only through spillover effects, but also through its influence on TFP. Hence, this article builds a TFP determination function in Equation 5 to identify the effect of international trade on TFP.

$$
T F P_{i t}=\alpha+\beta_{1} \text { trade }_{i t}+\beta_{2} \text { exratio }_{i t}+\beta_{3} H_{i t}+\delta P_{t}+\rho R_{i}+\theta Z_{i t}+\varepsilon_{i t}
$$

where $T F P_{i t}$ is the total factor productivity for nation $i$ at time $t$, which is derived from the production function in Equation 2. trade $_{i t}$ measures the total value of the international trade of agricultural products for nation $i$ at time $t$, in logarithm. exratio ${ }_{i t}$ accounts for the ratio of exports in total trade value in order to capture different effects of exports and imports on productivity. $H_{i t}=\sum_{j}\left(\omega_{i j t}^{\mathrm{II}} \cdot \omega_{i j t}^{\mathrm{II}}\right)$, the Herfindahl index of international trade, reflects the diversification of trade partners for nation $i$ at time $t$, where $\omega_{i j t}^{\mathrm{II}}$ are the elements in the trade-wide spatial weight matrix. A lower value of $H_{i t}$ implies that the trade volumes of nation $i$ are more evenly distributed to various trade partners, whereas a higher value of $H_{i t}$ shows that the trade portfolio is more diversified. To summarize, trade $_{i t}$ controls the size of international trade, exratio $_{i t}$ captures the characteristics of international trade, and $H_{i t}$ captures the distributions of international trade. $P$ is a vector of year dummy variables to capture time fixed effects and $R$ vectors a group of region dummy variables to capture the region fixed effects. Finally, $Z_{i t}$ vectors a group of other TFP determinants to deal with the endogeneity problem, which will be further discussed.

Endogeneity may also be a problem in the TFP determination (i.e. Equation 5) because of omitted variables or simultaneity bias. In terms of the former bias, this article employs $Z_{i t}$ in Equation 5, which vectors other TFP determinates adopted in the literature (Chen et al., 2008; Gong, 2018a; Gong et al., 2021), including the following: (1) the output share of crops in total agricultural products, crops $_{i t}$; (2) the share of cropland in total agricultural land cropland $_{i t} ;$ (3) the share of agricultural land that is irrigated, irrig $_{i t}$; (4) the geographic Herfindahl index, $\mathrm{Hgeo}_{i}=\sum_{j}\left(\omega_{i j}^{\mathrm{I}} \cdot \omega_{i j}^{\mathrm{I}}\right)$; and (5) a group of dummy variables of low-income $\left(L I_{i}\right.$, served as 
base group), lower middle-income $\left(M I_{-} L_{i}\right)$, upper middle-income $\left(M I_{-} U_{i}\right)$ and high-income $\left(H I_{i}\right)$ countries. Causality can be another issue, as some TFP determinants may be affected by productivity as well, which leads to simultaneity bias. For instance, international trade in agriculture may be conversely affected by agricultural productivity and may therefore lead to reverse causation. This article uses the instrumental variable (IV) method to overcome this issue, where the population size $\left(p o p_{i t}\right)$ recommended in Chanda and Dalgaard (2008), as well as the per capita agricultural production (agri_p $c_{i t}$ ) recommended in Madsen (2009), are employed as instruments for trade $i t$. Moreover, this article replaces all the independent variables with their lagged values to further deal with the causality problem. In order to break the potential serial correlation, independent variables that lagged two periods $(\mathrm{t}-2)$ are utilized, which can be regarded as a robustness check, as suggested in Guan et al. (2009) and Gong and Sickles (2021).

This article also investigates whether there is a bonus of international trade for GATT/WTO members. Furthermore, this article aims to test if the impact of international trade and the bonus for GATT/WTO members are different between less developed countries (LDCs) and developed countries (DCs). Accordingly, three interaction terms are added into the TFP determination equation, and the updated TFP determination function has the form:

$$
\begin{aligned}
\text {TFP }_{i t}= & \alpha+\beta_{1} \text { trade }_{i t}+\beta_{2} \text { trade }_{i t} \cdot \mathrm{mbr}_{i t}+\beta_{3} \text { trade }_{i t} \cdot \mathrm{DCs}_{i t}+\beta_{4} \text { trade }_{i t} \cdot \mathrm{mbr}_{i t} \times \mathrm{DCs}_{i t}+ \\
& \beta_{5} \text { exratio }_{i t}+\beta_{6} H_{i t}+\theta_{1} \text { crops }_{i t}+\theta_{2} \text { cropland }_{i t}+\theta_{3} \text { irrig }_{i t}+\theta_{4} \text { Hgeo }_{i}+\theta_{5} \text { MI L L L }_{i}+ \\
& \theta_{6} M I_{-} U_{i}+\theta_{7} H I_{i}+\theta_{8} \text { OECD }_{i t}+\theta_{9} \text { APEC }_{i t}+\delta P_{t}+\rho R_{i}+\varepsilon_{i t}
\end{aligned}
$$

where $m b r_{i t}$ is a dummy variable for GATT/WTO membership, and $D C s_{i t}$ is a dummy variable for developed countries. Therefore, $\beta_{1}$ accounts for the impact of international trade for LDCs without GATT/WTO membership; $\beta_{2}$ measures if receiving a GATT/WTO membership can help these LDCs to achieve a bonus of international trade; $\beta_{3}$ indicates whether the impact of international trade for DCs are different from LDCs, both without GATT/WTO membership; and $\beta_{4}$ tells whether the bonus of becoming a GATT/WTO member is different between DCs and LDCs. In order to control the impact of other trade organization and economic cooperation, Equation 6 also control a dummy variable $O E C D_{i t}$ for the member of the Organization for Economic Co-operation and Development (OECD), as well as a dummy variable $A P E C_{i t}$ for the member of the Asian-Pacific Economic Cooperation (AEPC).

\section{Data}

The Economic Research Service of the United States Department of Agriculture (USDA-ERS) had published country-level agricultural input and output data ${ }^{3}$ for 1961-2014. Gross agricultural output reported in USDAERS, $Y_{i t}$, is originally from the Food and Agriculture Organization of the United Nations (FAO), which is the sum of the value of production of 189 crop and livestock commodities valued at constant, and global-average prices from 2004-2006 (in billion US\$). There are six types of agricultural inputs: agricultural land (land $i t$, in million hectares of rain-fed cropland equivalents), agricultural labor (labor ${ }_{i t}$, in million economically active adults), livestock capital on farms (livestock ${ }_{i t}$, in thousand cattle equivalents), total stock of farm machinery ${\text { ( } \text { machinery }_{i t} \text {, in million 40-CV tractor equivalents), fertilizer consumption (fertilizer }}_{i t}$, in million metric tons of $\mathrm{N}, \mathrm{P} 2 \mathrm{O} 5, \mathrm{~K} 2 \mathrm{O}$ ), and total animal feed ( feed $_{i t}$, in million metric tons of crops and crop processing residues in dry-matter equivalents).

Data for bilateral trade are collected from NBER-UN and CEPII-BACI databases. The NBER-UN database documents a set of bilateral trade data by commodity for 1962-2000 in Feenstra et al. (2005), which is available on the NBER website. CEPII-BACI is the world trade database(BACI) developed by the French research center in international economics (CEPII) (Gaulier and Zignago, 2010), which provides bilateral values and quantities of trade for 1995-2014 using data originally from the United Nations Statistical Division (COMTRADE database). For both NBER-UN and CEPII-BACI databases, this article generates the bilateral

\footnotetext{
${ }^{3}$ Available at: https://www.ers.usda.gov/data-products/international-agricultural-productivity/
} 
trade of agricultural products data based on the definition of agricultural products given by the Agreement on Agriculture of the World Trade Organization (WTO). Similar to Boschma and Capone (2015) and Johnson and Noguera (2017), this paper uses NBER-UN and CEPII-BACI to generate trade data for 1962-1994 and 1995-2014, respectively. It is worth noting that the bilateral trade matrix $\left(W_{2}\right)$, the trade Herfindahl index $\left(H_{i t}\right)$, and the country-level trade value and export ratio data $\left(\right.$ trade $_{i t}$ and exratio $\left.i t\right)$ can be calculated using these two databases.

The data of other variables are collected as follows: (1) geographic spatial weight matrix $\left(W_{1}\right)$ and geographic Herfindahl index $\left(\mathrm{Hgeo}_{i}\right)$ can be generated using the GeoDist datasets in CEPII; (2) the share of cropland in total agricultural land $\left(\right.$ cropland $\left._{i t}\right)$, the share of agricultural land that is irrigated $\left(\right.$ irrig $\left._{i t}\right)$, region dummy variables $(R)$, and dummy variables of low-income, lower middle-income, upper middle-income and highincome countries $\left(E_{i}\right)$, are all available from USDA-ERS, where our input and output data are collected; (3) the output share of crops in total agricultural products ( crops $_{i t}$ ) can be downloaded and computed from FAO's database; (4) GATT/WTO membership information $(m b r i t)$ is available on the WTO website; ${ }^{4}(5)$ Developed countries dummy variable $\left(D C s_{i t}\right)$ can be collected from the International Monetary Fund (IMF); (6) population size $\left(p_{p} p_{i t}\right)$ is collected from World Bank databases; (7) per capita agricultural production $\left(\right.$ agri $\left.p c_{i t}\right)$ can be computed using agricultural output from USDA-ERS and population data from World Bank databases; and (8) OECD and APEC membership information $\left(O E C D_{i t}\right.$ and $\left.A P E C_{i t}\right)$ are available on their website. ${ }^{5}$

Combining all the data mentioned above, this article is based on a balanced panel of 126 countries for 1962-2014 with a total of 6,678 observations. ${ }^{6}$ Table 1 provides summary statistics of the key variables in our panel data. On average, these 126 countries used 13.3 million hectares of agricultural land, 7.0 million workforce, 15,100 cattle equivalents of livestock capital, 0.2 million tractor equivalents of farm machinery, 0.8 million metric tons of fertilizer, and 6.7 million metric tons of feed to generate agricultural products that value 10.3 billion international dollars at 2005 's constant price. In terms of trade, each nation, on average, had 5.9 billion dollars of international trade in agricultural products, the average export ratio is 0.51 and the trade Herfindahl index is 0.17 . During the same period, $79 \%$ of the agricultural land is cropland, and $12 \%$ of the agricultural land is equipped for irrigation. The average ratio of crops in agricultural output is $60 \%$ and the remaining $40 \%$ is composed of livestock-related products. Finally, the sample countries, on average, had a population of 36 million and per capita agricultural products valued at 310 international dollars at 2005's constant price.

\section{Estimation results}

This empirical study applies the models to the balanced panel of 126 nations from 1961-2014. First, the control function test shows that five inputs, including land, labor, machinery, fertilizer and animal feed, are endogenous, which are corrected by the IV method suggested in Amsler et al. (2016) using lagged values of the inputs as instruments (Levinsohn and Petrin, 2003). Second, this article uses the Breusch-Pagan LM test (Breusch and Pagan, 1980) and the Pesaran CD test (Pesaran, 2004) to assess the cross-sectional dependence, both of which generate $P$-values of less than 0.05 . Therefore, cross-sectional dependence exists. Third, this article adopts Moran's $I$ test for spatial autocorrelation using geographic and trade spatial weights matrices $W_{1}$ and $W_{2}$, separately, both of which derive $P$-values of less than 0.05 and thus confirm the existence of spatial autocorrelation geographic-wide and trade-wide. Finally, this paper confirms that SAR model is the

\footnotetext{
4 Information of GATT members by 1994 and WTO members since 1995 are respectively available at: https:/www.wto.org/english/thewto_e/ gattmem_e.htm and https://www.wto.org/english/thewto_e/whatis_e/tif_e/org6_e.htm.

5 Information of OECD members and APEC members are respectively available at: https://www.oecd.org/ and https://www.apec.org/.

${ }^{6}$ Inputs data in 1961 are used to check the endogeneity of inputs in the production function. Other countries were excluded because some variables are missing. The 126 countries selected account for over $90 \%$ of the world's total agricultural production in 2014.
} 
Table 1. Summary statistics.

\begin{tabular}{lllllll}
\hline Variable name & Notation & Unit & Mean & St. Dev. & Min & Max \\
\hline agricultural output & Y & billion US\$ & 10.3 & 34.9 & 0.0 & 591 \\
agricultural land & land & million hectares & 13.3 & 40.0 & 0.0 & 316 \\
agricultural labour & labor & million active adults & 7.0 & 33.0 & 0.0 & 391 \\
livestock capital & livestock & thousand cattle equivalents & 15.1 & 43.4 & 0.0 & 415 \\
farm machinery & machine & million tractor equivalents & 0.2 & 0.7 & 0.0 & 11.7 \\
fertilizer consumption & fertilizer & million metric tons & 0.8 & 3.4 & 0.0 & 51.4 \\
animal feed & feed & million metric tons & 6.7 & 23.3 & 0.0 & 371 \\
agricultural trade value & exp(trade) & billion dollars & 5.9 & 16.7 & 0.0 & 273 \\
agricultural export ratio & exratio & - & 0.51 & 0.26 & 0.0 & 1.0 \\
trade Herfindahl index & H & - & 0.17 & 0.12 & 0.04 & 0.93 \\
geographic Herfindahl index & Hgeo & - & 0.04 & 0.09 & 0.01 & 0.59 \\
share of cropland & cropland & - & 0.79 & 0.19 & 0.00 & 1.00 \\
share of irrigated land & irrig & - & 0.12 & 0.13 & 0.00 & 0.71 \\
share of crops output & crops & - & 0.60 & 0.23 & 0.01 & 1.00 \\
GATT/WTO membership & mbr & - & 0.68 & 0.47 & 0 & 1 \\
developed countries dummy & DCs & - & 0.18 & 0.38 & 0 & 1 \\
population size & pop & Million & 36 & 127 & 0.06 & 1,360 \\
per capita agricultural output & agripc & thousand US\$ & 0.31 & 0.28 & 0.00 & 2.58 \\
OECD membership & OECD & - & 0.17 & 0.38 & 0 & 1 \\
APEC membership & APEC & - & 0.06 & 0.24 & 0 & 1 \\
\hline
\end{tabular}

appropriate spatial model for the present dataset. ${ }^{7}$ To summarize, it is necessary to consider geographic-wide and trade-wide dependence and employ $W_{1}$ and $W_{2}$ to estimate the world agricultural production function using spatial models. This section first analyzes the effect of international trade in the full sample period and then emphasizes the changes in the GATT period (1962-1994) and the WTO period (1995-2014).

\subsection{Trade-driven spillovers: negative in the GATT era and positive in the WTO era}

Table 2 reports the estimation results of various spatial production functions in Equation 2 across different periods. The first two columns describe agricultural production in the full sample period (1962-2014), whereas the next two columns and the last two columns provide results in the GATT period (1962-1994) and the WTO period (1995-2014), respectively. For each pair of columns that focus on the same period, the first column uses spatial weight matrix $W_{1}$ to control geographic autocorrelation, whereas the second column uses spatial weight matrix $W_{2}$ to control trade autocorrelation.

For the full sample period, all six input elasticities are fairly robust in the first two columns in Table 2. The elasticities of land and livestock capital are the greatest ( 0.45 and 0.27 , respectively), followed by the elasticity of animal feed (0.11), while the elasticity of machinery and fertilizer are the lowest $(0.07$ and 0.06 , respectively). Moreover, the parametric $\rho$ in both dimensions are statistically positive, indicating both positive geographic-wide spillover effects and positive trade-wide spillover effects. More specifically, the spillover effects, measured by indirect effects, are 0.172 due to geographic proximity and 0.084 due to bilateral trade, respectively. Finally, the jackknife model averaging weights assigned to the dependence

\footnotetext{
${ }^{7}$ Weather and other variables that may cause spillover effects are included in the disturbance of the production function. Therefore, we can employ a General Spatial Model (GSM) rather than the SAR model, where the disturbance term is also assumed to be cross-sectional dependent, to check if the spillover exists. A GSM model has the form $y_{i t}=\rho \sum_{j=1}^{N} \omega_{i j} y_{j t}+X_{i t} \beta+\varepsilon_{i t}$, where $\varepsilon_{i t}=\lambda \sum_{j=1}^{N} \omega_{i j} \varepsilon_{j t}+u_{i t}$. I have checked the results of GSM, which are fairly robust with the ones in SAR. Model selection result also suggests using SAR rather than GSM based on AIC scores. Therefore, weather shocks and other factors in the disturbance do not significantly affect the estimates.
} 
Table 2. Estimation results. ${ }^{1,2}$

\begin{tabular}{|c|c|c|c|c|c|c|}
\hline \multirow[t]{2}{*}{ Output } & \multicolumn{2}{|c|}{ Full period (1962-2014) } & \multicolumn{2}{|c|}{ GATT period (1962-1994) } & \multicolumn{2}{|c|}{ WTO period (1995-2014) } \\
\hline & $W_{1}$ & $W_{2}$ & $W_{1}$ & $W_{2}$ & $W_{1}$ & $W_{2}$ \\
\hline Land & $\begin{array}{l}0.444 * * * \\
(0.011)\end{array}$ & $\begin{array}{l}0.450^{* * *} \\
(0.011)\end{array}$ & $\begin{array}{l}0.486^{* * *} \\
(0.014)\end{array}$ & $\begin{array}{l}0.490^{* * *} \\
(0.014)\end{array}$ & $\begin{array}{l}0.352^{* * *} \\
(0.020)\end{array}$ & $\begin{array}{l}0.343^{* * *} \\
(0.020)\end{array}$ \\
\hline Labor & $\begin{array}{l}0.050^{* * *} \\
(0.008)\end{array}$ & $\begin{array}{l}0.042^{* * * *} \\
(0.008)\end{array}$ & $\begin{array}{l}-0.023^{*} \\
(0.012)\end{array}$ & $\begin{array}{l}-0.026^{* *} \\
(0.012)\end{array}$ & $\begin{array}{l}0.233^{* * * *} \\
(0.017)\end{array}$ & $\begin{array}{l}0.242^{* * *} \\
(0.017)\end{array}$ \\
\hline Livestock & $\begin{array}{l}0.272 * * * \\
(0.010)\end{array}$ & $\begin{array}{l}0.270^{* * *} \\
(0.010)\end{array}$ & $\begin{array}{l}0.326^{* * *} \\
(0.013)\end{array}$ & $\begin{array}{l}0.323^{* * *} \\
(0.013)\end{array}$ & $\begin{array}{l}0.166^{* * * *} \\
(0.016)\end{array}$ & $\begin{array}{l}0.165^{* * *} \\
(0.016)\end{array}$ \\
\hline Machine & $\begin{array}{l}0.069^{* * *} \\
(0.004)\end{array}$ & $\begin{array}{l}0.072 * * * \\
(0.004)\end{array}$ & $\begin{array}{l}0.059^{* * *} \\
(0.005)\end{array}$ & $\begin{array}{l}0.058^{* * *} \\
(0.005)\end{array}$ & $\begin{array}{l}0.087^{* * *} \\
(0.011)\end{array}$ & $\begin{array}{l}0.090^{* * *} \\
(0.011)\end{array}$ \\
\hline Fertilizer & $\begin{array}{l}0.059^{* * *} \\
(0.006)\end{array}$ & $\begin{array}{l}0.061 * * * \\
(0.004)\end{array}$ & $\begin{array}{l}0.050^{* * *} \\
(0.005)\end{array}$ & $\begin{array}{l}0.050^{* * *} \\
(0.005)\end{array}$ & $\begin{array}{l}0.018^{* * *} \\
(0.006)\end{array}$ & $\begin{array}{l}0.020^{* * *} \\
(0.006)\end{array}$ \\
\hline Feed & $\begin{array}{l}0.106^{* * *} \\
(0.006)\end{array}$ & $\begin{array}{l}0.105^{* * *} \\
(0.006)\end{array}$ & $\begin{array}{l}0.102 * * * \\
(0.007)\end{array}$ & $\begin{array}{l}0.105^{* * *} \\
(0.007)\end{array}$ & $\begin{array}{l}0.144^{* * * *} \\
(0.010)\end{array}$ & $\begin{array}{l}0.140^{* * *} \\
(0.010)\end{array}$ \\
\hline Time effects & controlled & controlled & controlled & controlled & controlled & controlled \\
\hline Nation effects & controlled & controlled & controlled & controlled & controlled & controlled \\
\hline Intercept & $\begin{array}{l}4.840 * * * \\
(0.042)\end{array}$ & $\begin{array}{l}5.001 * * * \\
(0.042)\end{array}$ & $\begin{array}{l}4.853^{* * *} \\
(0.049)\end{array}$ & $\begin{array}{l}4.996 * * * \\
(0.050)\end{array}$ & $\begin{array}{l}5.386^{* * * *} \\
(0.066)\end{array}$ & $\begin{array}{l}5.104 * * * \\
(0.066)\end{array}$ \\
\hline$\rho$ & $\begin{array}{l}0.147 * * * \\
(0.024)\end{array}$ & $\begin{array}{l}0.078^{* * *} \\
(0.029)\end{array}$ & $\begin{array}{l}0.056^{* * *} \\
(0.026)\end{array}$ & $\begin{array}{l}-0.060^{*} \\
(0.036)\end{array}$ & $\begin{array}{l}-0.032 \\
(0.035)\end{array}$ & $\begin{array}{l}0.529^{* * *} \\
(0.051)\end{array}$ \\
\hline Indirect effect & $\begin{array}{l}0.172 * * * \\
(0.038)\end{array}$ & $\begin{array}{l}0.084 * * * \\
(0.033)\end{array}$ & $\begin{array}{c}0.059^{*} \\
(0.030)\end{array}$ & $\begin{array}{l}-0.056^{*} \\
(0.030)\end{array}$ & $\begin{array}{l}-0.031 \\
(0.037)\end{array}$ & $\begin{array}{l}0.346^{* * *} \\
(0.100)\end{array}$ \\
\hline Sample size & 6,678 & 6,678 & 4,158 & 4,158 & 2,520 & 2,520 \\
\hline Jackknife $w_{m}^{*}$ & 0.16 & 0.84 & 0.35 & 0.65 & 0.00 & 1.00 \\
\hline
\end{tabular}

${ }^{1}$ Standard errors are given in parentheses. ${ }^{*},{ }^{* *}, * * *$ indicate statistical significance at the 10,5 and $1 \%$ level.

${ }^{2}$ GATT $=$ general agreement on tariffs and trade; $\mathrm{WTO}=$ world trade organization.

in these two dimensions are 0.16 and 0.84 , indicating that cross-country dependence is mainly related to international trade.

Comparing with the GATT period, the contributions of labor, animal feed and farm machinery to agricultural production were greater, whereas the importance of the other three inputs relatively decreased in the WTO period. During the GATT period, geographic spillover effects ( $\rho$ is 0.056 and indirect effects are 0.059) were positive, whereas international trade caused negative spillover effects $(\rho$ is -0.06 and indirect effects are -0.056). In the WTO period, however, international trade led to significant positive spillover effects $(\rho$ is 0.529 and indirect effects are 0.346), which implies that the advantage of international trade was enjoyed in the agricultural sector. Moreover, the jackknife weight assigned to trade-wide dependence rose from 0.65 in the GATT period to 1.00 in the WTO period, which further confirms that the importance of international trade was increasing and that geographical distance was no longer a barrier in the WTO era.

\subsection{Effect on productivity: negative in the GATT era and positive in the WTO era}

The previous subsection estimates the spatial production functions with different spatial weights matrices and their corresponding jackknife model averaging weights, which can derive total factor productivity (TFP). Table 3 reports the estimated results of the TFP determination equation. The result of the full sample period is given in the first two columns, while the results of the GATT and WTO periods are separately listed in the next two columns and the last two columns. For each pair of columns that cover the same period, the first column reports the result of IV regression without the interaction terms (i.e. Equation 5) to estimate the average effect of international trade on productivity, whereas the second column reports the IV results with 
Table 3. Total factor productivity determination regression results. ${ }^{1,2}$

\begin{tabular}{|c|c|c|c|c|c|c|}
\hline \multirow{2}{*}{$\begin{array}{l}\text { TFP } \\
\text { determinants }\end{array}$} & \multicolumn{2}{|c|}{ Full period (1962-2014) } & \multicolumn{2}{|c|}{ GATT period (1962-1994) } & \multicolumn{2}{|c|}{ WTO period (1995-2014) } \\
\hline & (1) & $(2)$ & (3) & (4) & (5) & (6) \\
\hline trade & $\begin{array}{l}-0.003 \\
(0.012)\end{array}$ & $\begin{array}{l}-0.014 \\
(0.012)\end{array}$ & $\begin{array}{l}-0.034^{*} \\
(0.018)\end{array}$ & $\begin{array}{l}-0.038^{* *} \\
(0.018)\end{array}$ & $\begin{array}{l}0.043^{* * *} \\
(0.016)\end{array}$ & $\begin{array}{l}0.042^{* * *} \\
(0.015)\end{array}$ \\
\hline trade $\cdot m b r$ & $\begin{array}{l}- \\
-\end{array}$ & $\begin{array}{l}0.004^{* * *} \\
(0.001)\end{array}$ & $\begin{array}{l}- \\
-\end{array}$ & $\begin{array}{c}0.001 \\
(0.002)\end{array}$ & $\begin{array}{l}- \\
-\end{array}$ & $\begin{array}{l}0.004^{* *} \\
(0.002)\end{array}$ \\
\hline trade $\cdot D C s$ & - & $\begin{array}{c}0.014 \\
(0.009)\end{array}$ & - & $\begin{array}{l}-0.011 \\
(0.011)\end{array}$ & - & $\begin{array}{l}- \\
-\end{array}$ \\
\hline trade $\cdot m b r \cdot D C s$ & $\begin{array}{l}- \\
-\end{array}$ & $\begin{array}{l}-0.002 \\
(0.009)\end{array}$ & $\begin{array}{l}- \\
-\end{array}$ & $\begin{array}{c}0.001 \\
(0.010)\end{array}$ & $\begin{array}{l}- \\
-\end{array}$ & $\begin{array}{l}0.029 * * * \\
(0.003)\end{array}$ \\
\hline exratio & $\begin{array}{l}0.128^{* * *} \\
(0.028)\end{array}$ & $\begin{array}{l}0.108^{* * *} \\
(0.028)\end{array}$ & $\begin{array}{c}0.032 \\
(0.039)\end{array}$ & $\begin{array}{c}0.021 \\
(0.040)\end{array}$ & $\begin{array}{l}0.552 * * * \\
(0.047)\end{array}$ & $\begin{array}{l}0.546^{* * *} \\
(0.045)\end{array}$ \\
\hline$H$ & $\begin{array}{l}0.225^{* * *} \\
(0.065)\end{array}$ & $\begin{array}{l}0.254^{* * * *} \\
(0.065)\end{array}$ & $\begin{array}{l}0.363^{* * *} \\
(0.092)\end{array}$ & $\begin{array}{l}0.369^{* * *} \\
(0.092)\end{array}$ & $\begin{array}{l}0.280 * * * \\
(0.106)\end{array}$ & $\begin{array}{l}0.527^{* * *} \\
(0.107)\end{array}$ \\
\hline crops & $\begin{array}{l}-0.174 * * * \\
(0.025)\end{array}$ & $\begin{array}{l}-0.158^{* * *} \\
(0.025)\end{array}$ & $\begin{array}{l}-0.121^{* * *} \\
(0.035)\end{array}$ & $\begin{array}{l}-0.122^{* * *} \\
(0.035)\end{array}$ & $\begin{array}{l}-0.285^{* * *} \\
(0.039)\end{array}$ & $\begin{array}{l}-0.237^{* * *} \\
(0.038)\end{array}$ \\
\hline cropland & $\begin{array}{l}1.249^{* * *} \\
(0.044)\end{array}$ & $\begin{array}{l}1.219^{* * *} \\
(0.044)\end{array}$ & $\begin{array}{l}1.362^{* * *} \\
(0.065)\end{array}$ & $\begin{array}{l}1.362^{* * *} \\
(0.065)\end{array}$ & $\begin{array}{l}1.163^{* * *} \\
(0.064)\end{array}$ & $\begin{array}{l}0.985^{* * *} \\
(0.063)\end{array}$ \\
\hline irrig & $\begin{array}{l}1.414^{* * *} \\
(0.060)\end{array}$ & $\begin{array}{l}1.344^{* * * *} \\
(0.061)\end{array}$ & $\begin{array}{l}1.681^{* * *} \\
(0.092)\end{array}$ & $\begin{array}{l}1.678^{* * *} \\
(0.093)\end{array}$ & $\begin{array}{l}1.412^{* * *} \\
(0.082)\end{array}$ & $\begin{array}{l}1.204^{* * *} \\
(0.080)\end{array}$ \\
\hline Hgeo & $\begin{array}{l}1.866^{* * *} \\
(0.068)\end{array}$ & $\begin{array}{l}1.870^{* * *} \\
(0.068)\end{array}$ & $\begin{array}{l}2.105^{* * *} \\
(0.096)\end{array}$ & $\begin{array}{l}2.110^{* * *} \\
(0.096)\end{array}$ & $\begin{array}{l}1.755^{* * *} \\
(0.100)\end{array}$ & $\begin{array}{l}1.777^{* * *} \\
(0.095)\end{array}$ \\
\hline$M I \_L_{i}$ & $\begin{array}{l}0.186^{* * *} \\
(0.023)\end{array}$ & $\begin{array}{l}0.172^{* * *} \\
(0.023)\end{array}$ & $\begin{array}{l}0.237^{* * * *} \\
(0.035)\end{array}$ & $\begin{array}{l}0.235^{* * *} \\
(0.035)\end{array}$ & $\begin{array}{l}0.117^{* * * *} \\
(0.032)\end{array}$ & $\begin{array}{l}0.069^{* *} \\
(0.031)\end{array}$ \\
\hline$M I \_U_{i}$ & $\begin{array}{l}0.302^{* * *} \\
(0.027)\end{array}$ & $\begin{array}{l}0.287^{* * *} \\
(0.027)\end{array}$ & $\begin{array}{l}0.385^{* * *} \\
(0.040)\end{array}$ & $\begin{array}{l}0.379^{* * *} \\
(0.040)\end{array}$ & $\begin{array}{l}0.246^{* * *} \\
(0.037)\end{array}$ & $\begin{array}{l}0.183^{* * *} \\
(0.036)\end{array}$ \\
\hline$H I_{i}$ & $\begin{array}{l}0.757 * * * \\
(0.032)\end{array}$ & $\begin{array}{l}0.707 * * * \\
(0.032)\end{array}$ & $\begin{array}{l}0.879 * * * \\
(0.048)\end{array}$ & $\begin{array}{l}0.874^{* * * *} \\
(0.048)\end{array}$ & $\begin{array}{l}0.708^{* * *} \\
(0.042)\end{array}$ & $\begin{array}{l}0.548^{* * *} \\
(0.042)\end{array}$ \\
\hline$O E C D_{i t}$ & $\begin{array}{l}- \\
-\end{array}$ & $\begin{array}{l}-0.155^{* * *} \\
(0.031)\end{array}$ & $\begin{array}{l}- \\
-\end{array}$ & $\begin{array}{l}0.130^{* *} \\
(0.056)\end{array}$ & $\begin{array}{l}- \\
-\end{array}$ & $\begin{array}{l}-0.333^{* * *} \\
(0.037)\end{array}$ \\
\hline$A P E C_{i t}$ & $\begin{array}{l}- \\
-\end{array}$ & $\begin{array}{l}0.272 * * * \\
(0.028)\end{array}$ & $\begin{array}{l}- \\
-\end{array}$ & $\begin{array}{l}0.275^{* * *} \\
(0.078)\end{array}$ & $\begin{array}{l}- \\
-\end{array}$ & $\begin{array}{l}0.288^{* * *} \\
(0.034)\end{array}$ \\
\hline Time effects & controlled & controlled & controlled & controlled & controlled & controlled \\
\hline Region effects & controlled & controlled & controlled & controlled & controlled & controlled \\
\hline Intercept & $\begin{array}{l}3.712 * * * \\
(0.146)\end{array}$ & $\begin{array}{l}3.885^{* * *} \\
(0.147)\end{array}$ & $\begin{array}{l}3.846^{* * *} \\
(0.211)\end{array}$ & $\begin{array}{l}3.899 * * * \\
(0.213)\end{array}$ & $\begin{array}{l}3.691 * * * \\
(0.227)\end{array}$ & $\begin{array}{l}3.849 * * * \\
(0.221)\end{array}$ \\
\hline Sample size & 6,678 & 6,678 & 4,158 & 4,158 & 2,520 & 2,520 \\
\hline
\end{tabular}

${ }^{1}$ Standard errors are given in parentheses. ${ }^{*}, * * * * *$ indicate statistical significance at the 10,5 and $1 \%$ level. There is no estimation for the coefficient of trade·DCs in Column 6, as all the developed countries are WTO members in the WTO period.

${ }^{2} \mathrm{GATT}=$ general agreement on tariffs and trade; TFP $=$ total factor productivity; $\mathrm{WTO}=$ world trade organization.

the interaction term (i.e. Equation 6) so that the different impact of international trade between GATT/WTO members and non-members, as well as the different impact of international trade between DCs and LDCs can be captured. More regression results and more robustness checks are provided in the Supplementary Material, all of which are fairly robust.

This article estimates the impacts of international trade on TFP from three dimensions, including the size of trade $\left(\right.$ trade $\left._{i t}\right)$, the characteristics of trade $\left(\right.$ exratio $\left._{i t}\right)$ and the distributions of trade $H_{i t}$. First and foremost, we are interested in the effect of trade volume when the characteristics and distributions of trade are controlled. 
On average, a $1 \%$ increase in the total volume of international trade could decrease agricultural TFP by $0.034 \%$ during the GATT period, but can increase agricultural TFP by $0.043 \%$ during the WTO period. Therefore, the size of trade had a negative effect on TFP in the first period, but a positive effect on TFP in the second period. During the full period, this effect is economically and statistically insignificant from zero, indicating no effect of international trade on productivity.

Furthermore, this article is interested in the difference between GATT/WTO members and non-members, as well as between DCs and LDCs, in terms of the effects of international trade on productivity across periods. In the GATT period, these four groups have no significant difference, as the coefficients of all three interaction terms in Column 4 were insignificantly different from zero, which implies that DCs and LDCs both had identical and negative impact of international trade on productivity, and GATT members enjoyed no extra benefit from international trade compared with non-members. In the WTO period, LDCs without WTO membership can achieve a $0.042 \%$ increase in agricultural TFP from a $1 \%$ increase in the total volume of international trade. This increase can further improve by $0.004 \%$ for LDCs who received WTO membership, which implies that WTO accession helps LDCs to receive a small bonus on productivity from international trade. Moreover, we cannot identify the bonus of WTO membership for DCs, since all the DCs are WTO members. But on average, a $1 \%$ increase in the total volume of international trade can increase agricultural TFP by $0.075 \%$ for DCs, which is much larger than the one for LDCs $(0.042 \%)$. These findings show that there is no difference between LDCs and DCs and no difference between members and non-members in the GATT period, whereas the WTO provided small bonus from international trade to its members and greater improvement in productivity due to international trade is witnessed for DCs than for LDCs in the WTO period.

In terms of the characteristics of trade, exports are more preferred than imports, as the ratio of exports in trade has a positive effect on TFP. On average, a one percentage point increase in export ratio can raise TFP by more than $0.108 \%$ over the full period. However, this difference between exports and imports is only found in the WTO period. In terms of the distributions of trade, the diversification of trade partners can discourage TFP growth, as a negative effect of trade Herfindahl index is observed. Having more trade partners may expand trade volume, but when trade volume is controlled, the diversification of trade partners is not preferred. However, the disadvantage of having more trade partners diminished over time.

In terms of output portfolio, crops-related products are on average less productive than livestock-related products. During the full sample period, a one percentage point decrease in output share of crops, on average, increased TFP by $0.158 \%$. Moreover, the advantage in productivity of livestock-related products is enlarged from the GATT period to the WTO period. Considering the quality of land, cropland is more productive than pasture, and irrigated land is more productive than non-irrigated land. Moreover, both of the advantages of cropland and irrigated land are fairly consistent in the GATT period and the WTO period.

This article also finds that the TFP level for low-income, middle-income, and high-income countries are significantly different. Compared with low-income countries, lower middle-income countries on average were about $20 \%$ more productive, upper middle-income countries on average were $30 \%$ more productive, while high-income countries on average were around $70 \%$ more productive over the full period. Moreover, the productivity gap between low-income, lower middle-income, upper middle-income countries, and highincome countries diminished from GATT period to WTO period. Finally, the impact of OECD member on agricultural TFP changed from positive to negative from GATT period to WTO period, whereas the effect of APEC member is always positive.

\section{Conclusions and policy implications}

This article aims to evaluate the effects of international trade on global agricultural production. A spatial production model and a model averaging method are adopted to estimate country-level agricultural production when cross-country interactions due to geographical proximity and bilateral trade are jointly considered. 
This model not only captures the trade-driven spillover effects, but also leads to unbiased TFP. This article then estimates the effects of the size, characteristics, and distributions of international trade on TFP, which is the second impact of trade on agriculture, in addition to the spillover effects.

Using a panel of 126 countries from 1962-2014, this article evaluates the impact of international trade on agricultural productivity. In the GATT period, international trade caused negative spillover effects and hindered productivity growth. These results show that international trade and cooperation were not beneficial. In the WTO period, however, international trade not only generated positive spillover effects, but also improved the level of productivity. Moreover, the GATT did not offer extra benefits for its members, whereas the WTO provided a bonus through international trade to its members. Such findings provided evidence that the benefits of international trade and WTO accession are currently being enjoyed in agricultural production and should be further encouraged in the context of globalization. Finally, the impact of international trade on productivity is identical for DCs and LDCs in the GATT period, but DCs enjoyed much larger benefits due to international trade than LDCs in the WTO period. These empirical results are consistent with the fact that GATT was notable in largely excluding agriculture from trading rules whereas WTO brought agriculture into the world trade rules. Accordingly, this article generates the following policy implications.

Firstly, this article finds that WTO members, on average, enjoyed a greater positive effect of international trade on TFP compared with the non-member group, indicating the benefits of WTO accessions. The empirical result suggests that those countries that have not become WTO members should consider the bonus of becoming a member, especially the countries that already have a large volume of international trade.

Secondly, significant spillover effects and productivity growth in the agricultural sector have been brought about by international trade and enjoyed by both WTO members and non-members since the mid-1990s. Therefore, globalization and free trade should be encouraged and supported. Conversely, the consequences of anti-globalization and protectionism should be re-evaluated.

Thirdly, the coefficient of the trade Herfindahl index $\left(H_{i t}\right)$ is negative in both the GATT and WTO periods, which implies that the diversification of trade partners is not beneficial. In other words, major trade partners are more important than minor ones. As a result, governments should pay more attention to consolidating the relationships with their major partners where more cooperation and connection has already been established.

Finally, less developed countries benefited much less than developed countries from international trade in the WTO period. Since international trade brought severer competition, LDCs should pay more attention on how to learn from the imported commodities and how to update their technology for the exported products, which aims to encourage innovation and consequentially increases productivity.

\section{Supplementary material}

Supplementary material can be found online at https://doi.org/10.22434/IFAMR2021.0055

Appendix. Robustness checks.

\section{Acknowledgement, financial support}

The work was supported by the National Natural Science Foundation of China (72173114, 72161147001), Project of Leading Talents of Social Sciences in Zhejiang Province (21QNYC05ZD), Soft Science Research Program of Zhejiang Province (2020C25020), Qianjiang Talent Program (QJC1902008), Zhejiang Think Tank Research Project, and ZJU-IFPRI Center for International Development Studies at Zhejiang University. All authors contributed equally. The conclusions and recommendations, however, are the authors' and do not necessarily represent the positions of the institution. 


\section{Conflict of interest}

No conflict of interest exists in the submission of this manuscript.

\section{References}

Ackerberg, D.A., K. Caves and G. Frazer. 2015. Identification properties of recent production function estimators. Econometrica 83(6): 2411-2451.

Aghion, P. and R. Griffith. 2008. Competition and growth: reconciling theory and evidence. MIT Press, Cambridge, MA, USA.

Alcalá, F. and A. Ciccone. 2004. Trade and productivity. The Quarterly Journal of Economics 119(2): 613-646.

Amsler, C., A. Prokhorov and P. Schmidt. 2016. Endogeneity in stochastic frontier models. Journal of Econometrics 190(2): 280-288.

Anselin, L. 2001. Spatial effects in econometric practice in environmental and resource economics. American Journal of Agricultural Economics 83(3): 705-710.

Anselin, L. 2013. Spatial econometrics: methods and models. Vol. 4: Springer Science \& Business Media, Berlin, Germany.

Areal, F.J., K. Balcombe and R. Tiffin. 2012. Integrating spatial dependence into stochastic frontier analysis. Australian Journal of Agricultural and Resource Economics 56(4): 521-541.

Boschma, R. and G. Capone. 2015. Institutions and diversification: related versus unrelated diversification in a varieties of capitalism framework. Research Policy 44(10): 1902-1914.

Breusch, T.S. and A.R. Pagan. 1980. The Lagrange multiplier test and its applications to model specification in econometrics. The Review of Economic Studies 47(1): 239-253.

Brown-Kruse, J.L. 1991. Contestability in the presence of an alternate market: an experimental examination. The Rand Journal of Economics 22(1): 136-147.

Caragliu, A. and P. Nijkamp. 2012. The impact of regional absorptive capacity on spatial knowledge spillovers: the Cohen and Levinthal model revisited. Applied Economics 44(11): 1363-1374.

Chanda, A. and C.J. Dalgaard. 2008. Dual economies and international total factor productivity differences: channelling the impact from institutions, trade, and geography. Economica 75(3): 629-661.

Chen, P.C., Y.U. Ming-Miin, C.C. Chang and S.H. Hsu. 2008. Total factor productivity growth in China's agricultural sector. China Economic Review 19(4): 580-593.

Chen, S. and B. Gong. 2021. Response and adaptation of agriculture to climate change: evidence from China. Journal of Development Economics 148: 102557.

Cho, I.-K. and K. Kasa. 2017. Gresham's law of model averaging. American Economic Review 107(11): 3589-3616.

Cliff, A.D. and J.K. Ord. 1973. Spatial autocorrelation. Pion Ltd., London, UK.

Cohen, J.P. and C.J.M. Paul. 2004. Public infrastructure investment, interstate spatial spillovers, and manufacturing costs. The Review of Economics and Statistics 86(2): 551-560.

Curtis, R. and R.L. Hicks. 2000. The cost of sea turtle preservation: the case of Hawaii's pelagic longliners. American Journal of Agricultural Economics 82(5): 1191-1197.

Disdier, A.-C. and K. Head. 2008. The puzzling persistence of the distance effect on bilateral trade. The Review of Economics and Statistics 90(1): 37-48.

Druska, V. and W.C. Horrace. 2004. Generalized moments estimation for spatial panel data: Indonesian rice farming. American Journal of Agricultural Economics 86(1): 185-198.

Feenstra, R.C., R.E. Lipsey, H. Deng, A.C. Ma and H. Mo. 2005. World trade flows: 1962-2000. National Bureau of Economic Research, Cambridge, MA, USA.

Frankel, J.A. and D. Romer. 1999. Does trade cause growth? American Economic Review: 379-399.

Gaigné, C., J. Le Gallo, S. Larue and B. Schmitt. 2011. Does regulation of manure land application work against agglomeration economies? Theory and evidence from the French hog sector. American Journal of Agricultural Economics 94(1): 116-132.

Gaulier, G. and S. Zignago. 2010. BACI: international trade database at the product-level. The 1994-2007 version. CEPII research center, Paris, France. 
Gong, B. 2017. Multi-dimensional interactions in the oilfield market: a jackknife model averaging approach of spatial productivity analysis. Energy Economics 86: 103744. https://doi.org/10.1016/j. eneco.2017.08.032

Gong, B. 2018a. Agricultural reforms and production in China changes in provincial production function and productivity in 1978-2015. Journal of Development Economics 132: 18-31. https://doi.org/10.1016/j. jdeveco.2017.12.005

Gong, B. 2018b. The impact of public expenditure and international trade on agricultural productivity in China. Emerging Markets Finance and Trade 54(15): 3438-3453. https://doi.org/10.1080/154049 6X.2018.1437542

Gong, B. 2018c. Interstate competition in agriculture: cheer or fear? Evidence from the United States and China. Food Policy 81: 37-47.

Gong, B. 2020a. Agricultural productivity convergence in China. China Economic Review 60: 101423.

Gong, B. 2020b. New growth accounting. American Journal of Agricultural Economics 102(2): 641-661.

Gong, B. and R.C. Sickles. 2020. Non-structural and structural models in productivity analysis: study of the British Isles during the 2007-2009 financial crisis. Journal of Productivity Analysis 53(2): 243-263.

Gong, B. and R.C. Sickles. 2021. Resource allocation in multi-divisional multi-product firms. Journal of Productivity Analysis 55(2): 47-70.

Gong, B., S. Zhang, X. Liu and K.Z. Chen. 2021. The zoonotic diseases, agricultural production, and impact channels: evidence from China. Global Food Security 28: 100463.

Grossman, G.M. and E. Helpman. 1993. Innovation and growth in the global economy. MIT Press, Cambridge, MA, USA.

Guan, Z., S.C. Kumbhakar, R.J. Myers and A.O. Lansink. 2009. Measuring excess capital capacity in agricultural production. American Journal of Agricultural Economics 91(3): 765-776.

Han, J., D. Ryu and R. Sickles. 2016. How to measure spillover effects of public capital stock: a spatial autoregressive stochastic frontier model. In: B.H. Baltagi, J.P. LeSage and R.K. Pace (eds.) Spatial econometrics: qualitative and limited dependent variables. Emerald Group Publishing Limited, Bingley, UK, pp. 259-294.

Hansen, B.E. and J.S. Racine. 2012. Jackknife model averaging. Journal of Econometrics 167(1): 38-46.

Hansson, P. and M. Henrekson. 1994. A new framework for testing the effect of government spending on growth and productivity. Public Choice 81(3): 381-401.

Hardie, I.W., T.A. Narayan and B.L. Gardner. 2001. The joint influence of agricultural and nonfarm factors on real estate values: an application to the Mid-Atlantic region. American Journal of Agricultural Economics 83(1): 120-132.

Hassine, N.B. and M. Kandil. 2009. Trade liberalisation, agricultural productivity and poverty in the Mediterranean region. European Review of Agricultural Economics 36(1): 1-29.

Isik, M. 2004. Environmental regulation and the spatial structure of the US dairy sector. American Journal of Agricultural Economics 86(4): 949-962.

Johnson, R.C. and G. Noguera. 2017. A portrait of trade in value-added over four decades. Review of Economics and Statistics 99(5): 896-911.

Kelejian, H.H., P. Murrell and O. Shepotylo. 2013. Spatial spillovers in the development of institutions. Journal of Development Economics 101: 297-315.

LeSage, J.P. and R.K. Pace. 2009. Introduction to spatial econometrics. CRC Press, Boca Raton, FL, USA.

Levinsohn, J. and A. Petrin. 2003. Estimating production functions using inputs to control for unobservables. The Review of Economic Studies 70(2): 317-341.

Lucas, R.E. 1988. On the mechanics of economic development. Journal of Monetary Economics 22(1): 3-42.

Madsen, J.B. 2009. Trade barriers, openness, and economic growth. Southern Economic Journal 76(2): $397-418$.

Malik, A. and J.R. Temple. 2009. The geography of output volatility. Journal of Development Economics 90(2): 163-178.

Michaels, G. and X. Zhi. 2010. Freedom fries. American Economic Journal: Applied Economics 2(3): 256-281.

Miller, S.M. and M.P. Upadhyay. 2000. The effects of openness, trade orientation, and human capital on total factor productivity. Journal of Development Economics 63(2): 399-423. 
Moussa, I. and T. Laurent. 2015. Indirect and feedback effects as measure of knowledge spillovers in French regions. Applied Economics Letters 22(7): 511-514.

Ord, K. 1975. Estimation methods for models of spatial interaction. Journal of the American Statistical Association 70(349): 120-126.

Pesaran, M.H. 2004. General diagnostic tests for cross section dependence in panels. Institute for the Study of Labor (IZA), Bonn, Germany.

Petrick, M. 2016. Incentive provision to farm workers in post-socialist settings: evidence from East Germany and North Kazakhstan. International Food and Agribusiness Management Review 20: 239-255.

Roe, B., E.G. Irwin and J.S. Sharp. 2002. Pigs in space: modeling the spatial structure of hog production in traditional and nontraditional production regions. American Journal of Agricultural Economics 84(2): 259-278.

Romer, P.M. 1986. Increasing returns and long-run growth. Journal of Political Economy 94(5): 1002-1037.

Shang, C. 2015. Essays on the use of duality, robust empirical methods, panel treatments, and model averaging with applications to housing price index construction and world productivity growth. Rice University, Houston, TX, USA.

Yoo, C.K., M. Gopinath and H. Kim. 2012. Trade policy reform, productivity growth and welfare in South Korean agriculture. Applied Economic Perspectives and Policy 34(3): 472-488.

Yuan, L., S. Zhang, S. Wang, Z. Qian and B. Gong. 2021. World agricultural convergence. Journal of Productivity Analysis 55(2): 135-153. https://doi.org/10.1007/s11123-021-00600-5

Zhang, S., S. Wang, L. Yuan, X. Liu and B. Gong. 2020. The impact of epidemics on agricultural production and forecast of COVID-19. China Agricultural Economic Review 12(3): 409-425. 
